O. Yu. Maslov'1, S. V. Kolisnyk'1, S. V. Ponomarenko²,

E. Yu. Ahmedov' ${ }^{1}$ Z. V. Shovkova ${ }^{1}$

${ }^{1}$ National University of Pharmacy of the Ministry of Health of Ukraine, Ukraine

53, Pushkinska str., Kharkiv, 61002. E-mail: alexmaslov392@gmail.com

${ }^{2}$ Mechnikov Institute of Microbiology and Immunology of the National Academy

of Medical Sciences of Ukraine, Ukraine

\title{
The study of the effect of ethyl alcohol concentrations on the antioxidant activity of ascorbic acid solutions
}

Much attention is currently paid to the study of the antioxidant properties of various objects - individual antioxidants, dietary supplements, medicines, liquid plant extracts. Antioxidant medicines are widely used as the main or additional correction agents in the treatment of a number of diseases. Therefore, the study and development of procedures for determining the antioxidant activity is a prospective task for today.

Aim. To determine the contribution of different concentrations of ethanol to the level of the antioxidant activity (AOA) of ascorbic acid solutions by the potentiometric method.

Results and discussion. The different ethanol content in the solution had the following percent of the contribution to the value of AOA of ascorbic acid solutions - 1.85, 3.56, 4.89, 6.76, 7.63\% for 20,40,60,80,96\% ethanol, respectively. The linearity of the procedure was proven in the range from 0.039 to $0.31 \mathrm{mmol} / \mathrm{L}$.

Experimental part. The object of the study was solutions of ascorbic acid prepared using ethanol of different concentrations - 20,40,60,80,96\%. Potentiometric measurements were conducted by a Hanna $2550 \mathrm{pH}$ meter (Germany) with an EZDO 5010 combined platinum electrode. Weighing was carried out using an AN100 digital analytical balance (AXIS, Ukraine) with $d=0.0001 \mathrm{~g}$. Ascorbic acid was purchased from Sigma Aldrich $(\geq 99.0 \%), \mathrm{K}_{3}\left[\mathrm{Fe}(\mathrm{CN})_{6}\right], \mathrm{K}_{4}\left[\mathrm{Fe}(\mathrm{CN})_{6}\right], \mathrm{NaHPO}_{4}, \mathrm{KH}_{2} \mathrm{PO}_{4}$ were of analytical grade.

Conclusions. It has been found that ethyl alcohol affects the change of the potential in the electrochemical cell and the level of AOA of ascorbic acid solutions. The percentage of the contribution of different concentrations of ethyl alcohol to the AOA value ranges from 1.85 to $7.63 \%$. The approach and the formula for calculation that take into account the effect of ethyl alcohol on the final AOA result of the test sample of ascorbic acid in a water-alcohol solutions have been proposed. The results of this study can be used in the pharmaceutical and food industries to determine, assess and control the AOA level of dietary supplements, liquid extracts, tinctures, medicines, and alcoholic beverages.

Key words: effect of ethanol; ascorbic acid; antioxidant activity; potentiometric method

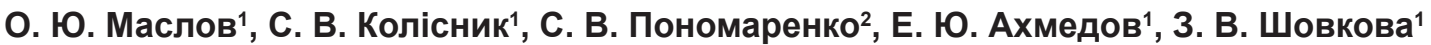

${ }^{1}$ Національний фрармацевтичний університет Міністерства охорони здоров'я України, Україна

${ }^{2}$ ДУ «Інститут мікробіології та імунології ім. І. І. Мечникова» Національної академії медичних наук

України, Україна

Дослідження впливу концентрації етилового спирту на антиоксидантну активність розчинів аскорбінової кислоти

У цей час велику увагу приділяють вивченню антиоксидантних властивостей різних об'єктів - індивідуальних антиоксидантів, дієтичних добавок, лікарських препаратів, настоянок, рідких екстрактів рослин. Антиоксидантні препарати широко використовують як основний або додатковий коригувальний засіб у лікуванні захворювань. Тому вивчення і розроблення методики визначення антиоксидантної активності наразі $€$ актуальним завданням.

Мета. За допомогою потенціометричного методу визначити залежність рівня антиоксидантної активності (АОА) розчинів аскорбінової кислоти від концентрації етанолу.

Результати та їх обговорення. Різний вміст етанолу в розчині мав такий відсоток внеску в значення антиоксидантної активності розчинів аскорбінової кислоти - 1,85, 3,56, 4,89, 6,76, 7,63\% для 20, 40, 60, $8096 \%$ етанолу відповідно. Доведено лінійність методики в діапазоні від 0,039 до 0,31 ммоль/л.

Експериментальна частина. Об'єктом дослідження були розчини аскорбінової кислоти, приготовлені з використанням етанолу різної концентрації - 20, 40, 60, 80, 96\%. Потенціометричні вимірювання проводили на pH-метрі Hanna 2550 (Німеччина) з комбінованим платиновим електродом EZDO 5010. Зважування проводили за допомогою цифрових аналітичних ваг AN100 (AXIS, Україна) з d = 0,0001 г. Аскорбінова кислота виробництва Sigma Aldrich ( $\geq 99,0 \%) ; \mathrm{K}_{3}\left[\mathrm{Fe}(\mathrm{CN})_{6}\right], \mathrm{K}_{4}\left[\mathrm{Fe}(\mathrm{CN})_{6}\right], \mathrm{NaHPO}_{4}, \mathrm{KH}_{2} \mathrm{PO}_{4}$ кваліфрікації «хімічно чистий».

Висновки. З'ясовано, що етиловий спирт впливає на зміну потенціалу електрохімічної комірки й рівень АОА розчинів аскорбінової кислоти. Відсоток внеску етилового спирту різних концентрацій в значення АОА перебуває в діапазоні від 1,85 до 7,63\%. Запропоновано підхід і фрормулу обчислення, що враховує вплив етилового спирту на кінцевий результат АОА досліджуваного зразка аскорбінової кислоти у водно-спиртовому розчині. Результати цього дослідження можуть бути використані у фармацевтичній і харчовій промисловості для визначення, оцінювання та контролю рівня АОА дієтичних добавок, рідких екстрактів, настоянок, лікарських препаратів, алкогольних напоїв.

Ключові слова: ефект етанолу; аскорбінова кислота; антиоксидантна активність; потенціометричний метод 
Free radicals are the main cause of the development of such serious diseases as radiation sickness, atherosclerosis, myocardial infarction, diabetes, cancer diseases. Living cells have a perfect antioxidant defense system that regulates the formation of free radicals (FR) and limits their accumulation in cells. Nevertheless, sometimes it is not enough, and therapy with the inclusion of antioxidants (AO) is increasingly used in the treatment of a number of diseases. Therefore, the production of branded antioxidants, including various components of natural or synthetic origin, is expanding [1].

Methods for studying the total antioxidant activity (AOA) can be divided by the type of the oxidation source, the oxidized compound, and the method of measuring AOA. In practice, the antioxidant activity is determined when conducting nonselective reactions with an oxidant, generating radicals, and measuring the electrochemical, kinetic, optical and other properties of indicator systems in the course of the reactions [2].

Electrochemical methods of analysis are based on the donor-acceptor reactions between $\mathrm{AO}$ and FR. Single-electron transfer methods are characterized by high sensitivity, the rapid analysis procedure, a relatively low cost of equipment and reagents, and hence, the analysis as a whole [3]. These methods include the potentiometric method based on the chemical interaction of $\mathrm{AO}$ with a mediator system, which is a mixture of $\mathrm{K}_{3}\left[\mathrm{Fe}(\mathrm{CN})_{6}\right] / \mathrm{K}_{4}\left[\mathrm{Fe}(\mathrm{CN})_{6}\right]$ [4]. Addition of solutions containing substances exhibiting AOA to the cell leads to a change in the redox potential of the medium as a result of the interaction of $\mathrm{AO}$ with the oxidizing component $\mathrm{K}_{3}\left[\mathrm{Fe}(\mathrm{CN})_{6}\right]$ of the mediator system $[5,6]$. In some research works $[7,8]$ the determination of the AOA level of alcohol extracts of plants and fungi by the potentiometric method without studying the effect of ethyl alcohol concentration on the value of AOA was described. In our view, these results can be untrue as ethyl alcohol can be oxidized also and affect the value of AOA.

In order to find out the effect of the ethyl alcohol concentration on the AOA value, ascorbic acid was chosen as a model compound, for the following reasons. Firstly, ascorbic acid is a part of numerous tinctures, for example, a tincture from lemongrass seeds, and secondly, it is relatively readily dissolved in water, and in solutions of ethyl alcohol in various concentrations. Hence, the aim of the current study is to determine the contribution of different concentrations of ethanol to the AOA level of ascorbic acid solutions by the potentiometric method.

\section{Materials and methods}

$\mathrm{K}_{4}\left[\mathrm{Fe}(\mathrm{CN})_{6}\right], \mathrm{K}_{3}\left[\mathrm{Fe}\left(\mathrm{CN}_{6}\right)\right], \mathrm{KH}_{2} \mathrm{PO}_{4}, \mathrm{Na}_{2} \mathrm{HPO}_{4} \cdot 12 \mathrm{H}_{2} \mathrm{O}$ were of analytical grade, ascorbic acid was $\geq 99.0 \%$ (Sigma-Aldrich).

Potentiometric measurements were conducted by a Hanna 2550 pH meter (Germany) with an EZDO 5010 combined platinum electrode.
Preparation of the model solutions of ascorbic acid

Six model solutions of ascorbic acid with the concentration of $0.002 \mathrm{~mol} / \mathrm{L}$ were prepared by dissolving $0.087 \mathrm{~g}$ of ascorbic acid in $250.0 \mathrm{~mL}$ of distilled water or water/ethanol mixtures with the ethanol concentrations of $20,40,60,96 \%$.

To assess linearity, different aliquots of the model solutions of ascorbic acid were taken $(1.00 ; 3.00$; $5.00 ; 7.00 ; 9.00 \mathrm{~mL}$ ), after that each aliquot was placed in the electrochemical cell, and as the result, solutions with ascorbic acid concentrations of $0.039,0.11$, $0.18,0.25,0.31 \mathrm{mmol} / \mathrm{L}$, respectively, were obtained.

\section{The procedure of determining AOA}

A $2 \mathrm{mmol} / \mathrm{L}$ solution of $\mathrm{K}_{3}\left[\mathrm{Fe}(\mathrm{CN})_{6}\right]$ was prepared by weighing $0.8232 \mathrm{~g}$ into a $25.0 \mathrm{~mL}$ volumetric flask, dissolving the compound in distilled water and diluting to the volume with the same solvent. A $0.02 \mathrm{mmol} / \mathrm{L}$ solution of $\mathrm{K}_{4}\left[\mathrm{Fe}(\mathrm{CN})_{6}\right]$ was prepared by weighing $0.0921 \mathrm{~g}$ into a $250.0 \mathrm{~mL}$ volumetric flask, dissolving the compound in distilled water and diluting to the volume with the same solvent. Then a $5.00 \mathrm{~mL}$ aliquot of both solutions prepared was taken and transferred into a $250.0 \mathrm{~mL}$ volumetric flask and dilute to the volume with the phosphate buffer solution of $0.067 \mathrm{~mol} / \mathrm{L}$ concentration. $50.00 \mathrm{~mL}$ of the mediator solution prepared was transferred to the electrochemical cell. The initial potential of the mediator solution was measured. After the initial potential was determined, $1.00 \mathrm{~mL}$ of the aliquot of the solutions of ascorbic acid prepared was added, and a final potential was measured. Thus, the difference $(\Delta E)$ between the initial $\left(E_{0}\right)$ and final $\left(E_{1}\right)$ potentials was found. The shift of the potential is explained by the change of ratio of the oxidized and reduced forms of the mediator system as a result of the following chemical reaction:

$$
\mathrm{a}\left[\mathrm{Fe}(\mathrm{CN})_{6}\right]^{3-}+\mathrm{bAO}=\mathrm{a}\left[\mathrm{Fe}(\mathrm{CN})_{6}\right]^{4-}+\mathrm{bAO}_{\text {ox }}
$$

where: $\mathrm{AO}$ - is the antioxidant; $\mathrm{AO}_{\mathrm{ox}}$ - is an oxidized form of the antioxidant; $\mathrm{a}, \mathrm{b}$ - are stoichiometric coefficients.

The antioxidant activity was calculated by the following equation and expressed in $\mu \mathrm{mol} / \mathrm{L}$ :

$$
\mathrm{AOA}=\frac{C_{o X}-\alpha \cdot C_{r e d}}{1+\alpha} \times K_{d i l} \times 10^{6},
$$

where: $\alpha=C_{\text {ox }} / C_{\text {red }} \times 10^{\triangle E n F / 2.3 R T} ; C_{\text {ox }}-$ is $0.002 \mathrm{~mol} / \mathrm{L}$ of $\mathrm{K}_{3}\left[\mathrm{Fe}(\mathrm{CN})_{6}\right] ; C_{\text {red }}$ - is $0.00002 \mathrm{~mol} / \mathrm{L}$ of $\mathrm{K}_{4}\left[\mathrm{Fe}(\mathrm{CN})_{6}\right]$; $\Delta E$ - is the change of the potential; $F=96485.333 \mathrm{C} / \mathrm{mol}-$ is the Faraday constant; $n=1$ - is the number of electrons in the electrode reaction; $R=8.314 \mathrm{~J} /(\mathrm{mol} \times \mathrm{K})-$ is the universal gas constant; $T=298 \mathrm{~K} ; K_{d i l}-$ is the coefficient of dilution.

\section{Statistical analysis}

The statistical analysis was performed in Microsoft Excel 2010 with the accepted significance level of $\alpha=0.05$. Results were expressed as the mean \pm conditional interval from five measurements. 


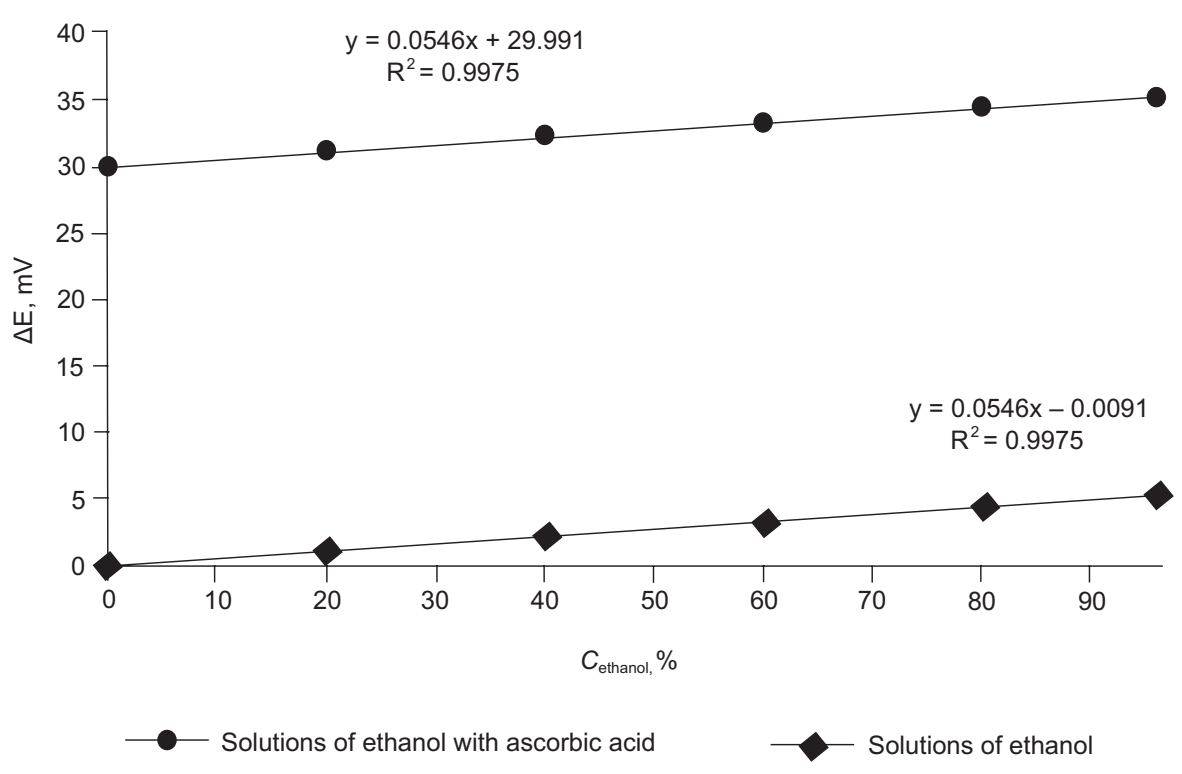

Fig. 1. The effect of the ethanol concentration on the potential difference in the electrochemical cell when determining AOA of ascorbic acid solutions

\section{Results and discussion}

When determining AOA of ascorbic acid AOA of ethyl alcohol with different concentrations was also studied. As a result, Fig. 1 shows that with an increase in the concentration of ethyl alcohol in the electrochemical cell the change in the potential also increases. In addition, in the case of solutions of ascorbic acid prepared using ethyl alcohol solutions of different concentrations the same situation can be observed. This is a clear evidence that ethanol interacts with $\mathrm{K}_{3}\left[\mathrm{Fe}\left(\mathrm{CN}_{6}\right)\right]$ and affects the determination of the AOA level of ascorbic acid solutions.

The contribution of ethyl alcohol can be explained by the fact that the hydroxyl group presented in its structure can be oxidized by $\mathrm{K}_{3}\left[\mathrm{Fe}\left(\mathrm{CN}_{6}\right)\right]$ to give the aldehyde group. As a result, the oxidation of ethanol leads to the extra contribution in the AOA value of ascorbic acid solutions. Hence, when determining AOA by the potentiometric method the contribution of ethyl alcohol and its concentration should be taken into account.
In order to "extract" the true value of ascorbic acid AOA from the total change of the potential obtained during the analysis of the sample, the latter should be reduced by an amount corresponding to the concentration of ethyl alcohol in the sample analyzed. According to the results obtained ethanol in different concentrations has the following percent of contribution to AOA: 1.85, 3.56, 4.89, 6.76, 7.63\% for 20, 40, $60,80,96 \%$ ethanol, respectively. According to this, $96 \%$ ethanol has the greatest effect on determining AOA, whereas $20 \%$ ethanol possesses the lowest one. The results obtained are given in the Table.

Therefore, to calculate the AOA value of the test sample (liquid extract, tincture, individual substances prepared in aqueous-alcohol and alcohol-aqueous solutions) the following equation, including the ethanol contribution, should be used:

$$
\mathrm{AOA}=\frac{C_{o x}-\alpha \cdot C_{r e d}}{1+\alpha} \times K_{\text {dil }} \times 10^{6},
$$

where $\alpha=C_{\text {ox }} / C_{\text {red }} \times 10^{\left(\Delta E-E_{\text {ethanol) }} \mathrm{F} / 2.3 R T\right.} ; C_{\text {ox }}$ - is the concentration of $\mathrm{K}_{3}\left[\mathrm{Fe}(\mathrm{CN})_{6}\right]$, mol/L; $C_{\text {red }}$ - is the concentration

Table

The results of determining AOA of the solutions of ascorbic acid

\begin{tabular}{|l|c|c|c|c|c|c|}
\hline & \multicolumn{6}{|c|}{ Solvent } \\
\cline { 2 - 7 } & water & $20 \%$ & $40 \%$ & $60 \%$ & $80 \%$ & $96 \%$ \\
\hline $\begin{array}{l}\Delta E \text { of ascorbic acid solutions, } \\
\mathrm{mV}\end{array}$ & 30 & 31.1 & 32.2 & 33.1 & 34.5 & 35.2 \\
\hline$\Delta E$ of ethanol solutions, $\mathrm{mV}$ & 0 & 1.1 & 2.2 & 3.1 & 4.5 & 5.2 \\
\hline $\begin{array}{l}\text { AOA without taking into } \\
\text { account ethanol, } \mu \mathrm{mol} / \mathrm{L}\end{array}$ & $3449 \pm 7.42$ & $3515 \pm 10.43$ & $3577.5 \pm 5.17$ & $3627.5 \pm 16.39$ & $3700 \pm 17.15$ & $3735 \pm 11.18$ \\
\hline $\begin{array}{l}\text { AOA minus the contribution } \\
\text { of ethanol, } \mu \mathrm{mol} / \mathrm{L}\end{array}$ & 0 & 65 & 127.5 & 177.5 & 250 & 285 \\
\hline Contribution of ethanol, $\%$ & 0 & 1.85 & 3.56 & 4.89 & 6.76 & 7.63 \\
\hline
\end{tabular}




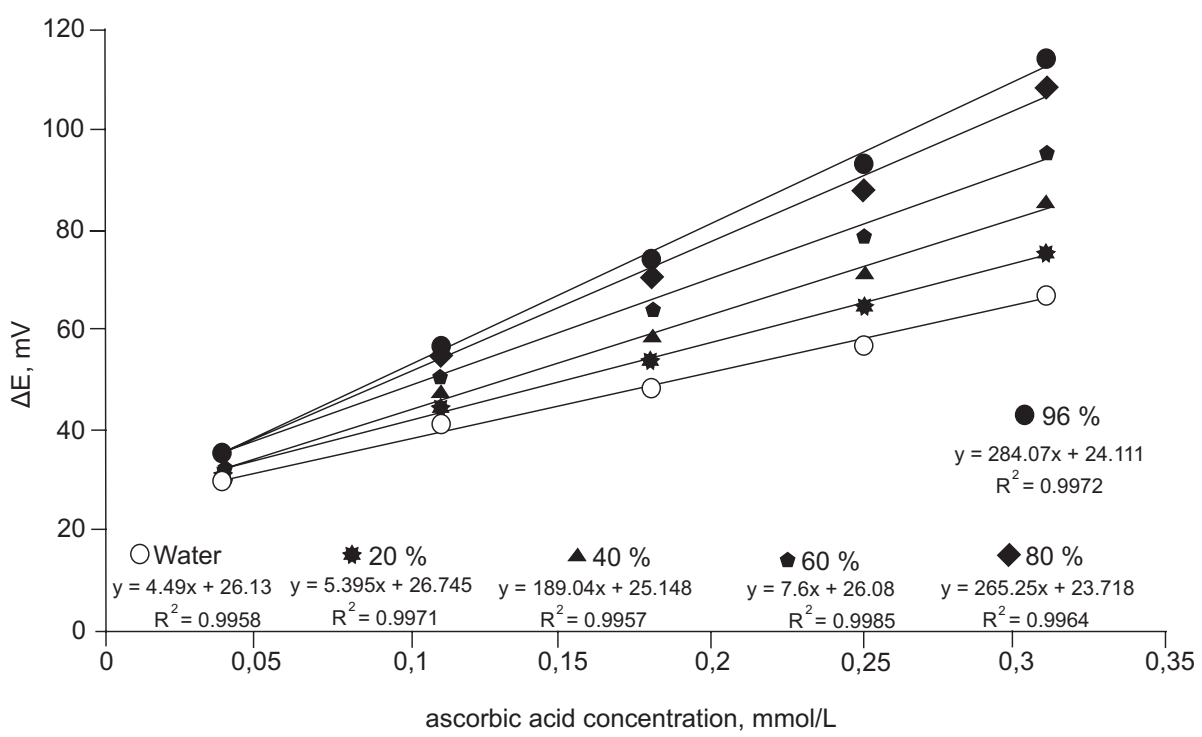

Fig. 2. Calibration curves of $\Delta E$ vs concentration of the ascorbic acid solutions

of $\mathrm{K}_{4}\left[\mathrm{Fe}(\mathrm{CN})_{6}\right]$, mol/L; $E_{\text {ethanol }}=\left(0.0546 \times \mathrm{C}_{\text {ethanol, } \%}-0.0091\right)$ taken from Fig. 1; $C_{\text {ethanol, } \%}$ - is the concentration of ethanol; $\Delta E$ - is the change of the potential; $F=96485.333 \mathrm{C} / \mathrm{mol}-$ is the Faraday constant; $n=1$ - is the number of electrons in the electrode reaction; $R=8.314 \mathrm{~J} /(\mathrm{mol} \times \mathrm{K})-$ is the universal gas constant; $T=298 \mathrm{~K} ; K_{d i l}$ - is the coefficient of dilution.

The linearity was proven in the range of ascorbic acid concentrations from 0.039 to $0.31 \mathrm{mmol} / \mathrm{L}$. Calibration curves of the potential change dependence on the concentration of ascorbic acid were plotted (Fig. 2). The regression equations and $\mathrm{R}^{2}$ of the curves obtained are: $\mathrm{y}=4.49 \mathrm{x}+26.13, \mathrm{R}^{2}=0.9958$ for the water solution of ascorbic acid; $y=5.395 x+26.745$, $\mathrm{R}^{2}=0.9971$ for $20 \%$ ethanol solution of ascorbic acid; $y=189.04 x+25.148, R^{2}=0.9957$ for $40 \%$ ethanol solution of ascorbic acid; $y=7.6 x+26.08, R^{2}=0.9985$ for $60 \%$ ethanol solution of ascorbic acid; $y=265.25 x+$ $23.718, \mathrm{R}^{2}=0.9964$ for $80 \%$ ethanol solution of ascorbic acid; $y=284.07 x+24.111, R^{2}=0.9974$ for $96 \%$ ethanol solution of ascorbic acid. Therefore, there is a direct linear relation between the change of the potential in the electrochemical cell and the concentration of ascorbic acid in different solvents.

\section{Conclusions}

It has been found that the concentration of ethyl alcohol affects the change of the potential in the electrochemical cell and the level of AOA of ascorbic acid solutions. The percentage of the contribution of ethyl alcohol to the AOA value ranges from 1.85 to $7.63 \%$.

The approach and the formula for calculation that take into account the effect of ethyl alcohol on the final AOA result of the test sample in a water-alcohol solutions have been proposed.

The results of this study can be used in the pharmaceutical and food industries to determine, assess and control the AOA level of dietary supplements, liquid extracts, tinctures, medicines, and alcoholic beverages.

Conflict of interests: the authors have no conflict of interests to declare.

\section{References}

1. Я Яшин, А. Я.; Яшин, Я. И.; Черноусова, Н. И.; Федина, П. А.; Немзер, Б. В. Методы определения антиоксидантной активности пищевых продуктов и БАДов Мир измерений 2012, 1, 30-35.

2. Вяткин, А. В.; Пастушкова, Е. В.; Феофилактова, О. В. Обзор методов определения общей антиоксидантной активности. Современная наука и инновации 2018, 1, 58-66.

3. Trineeva, O. V. Methods of determination of antioxidant activity of plant and synthetic origins in pharmacy (review). Drug development \& registration 2017, 4, 180-197.

4. Ivanova, A. V.; Gerasimova, E. L.; Brainina, K. Z. Potentiometric Study of Antioxidant Activity: Development and Prospects. Crit. Rev. Anal. Chem. 2015, 45 (4), 311-322. https://doi.org/10.1080/10408347.2014.910443.

5. Measurement of Antioxidant Activity \& Capacity: Recent Trends and Applications; Apak, R.; Capanoglu, E.; Shahide, F., Eds.; John Wiley \& Sons: 2017.

6. Tarasov, A. V.; Bukharinova, M. A.; Khamzina, E. I. Aqueous Extracts Antioxidant Activity Determination of Some Plants from the Ural Region. Food Chemistry and Hygiene 2018, 3 (2), 31-38. https://doi.org/10.29141/2500-1922-2018-3-2-5

7. Gevorgyan, V. S.; Nanagulyan, S. G.; Chantikyan, A. A.; Seferyan, T. Ye. Assessment of antioxidant activities of some medicinal fungal extracts. Proceedings of the Yerevan State University, Chemistry and Biology 2017, 51 (3), 163-165.

8. Lupak, O.; Kovalchuk, H.; Antonyak, H. Potentiometric determination of antioxidant activity of extracts of Calendula Officinalis L. plants under the influence of growth biostimulants. ScienceRise: Biological Science 2017, 6 (9), 10-13. https://doi.org/10.15587/2519-8025.2017.119086

The work is a part of researches of the National University of Pharmacy on the topic «Organic synthesis and analysis of biologically active compounds, drugs development on the basis of synthetic substances» (the state registration No. 01144000943;

the research period 2019-2024) 